\title{
Examining Effects of Physical Education and Fine Arts Education on Mental Skills
}

\author{
Meliha Uzun Dönmez ${ }^{1 \rtimes}$ \\ Osman İmamoğlu
}

'Sirnak University, High school of Physical Education and Sports, Sirnak, Turkey. Email:melihauzunn16@gmail.com

'Ondokuz Mayıs University, Faculty of Sports Science, Samsun, Turkey.

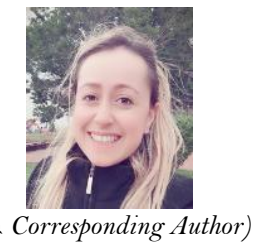

\section{Abstract}

The aim of this study was to investigate effects of physical education and fine arts education on mental skills for University students. The study included 344 university students fulfilling The Ottawa Mental Skills Assessment Tool completely. Obtained data were statistically analyzed with $t$ test. While there was no significant difference in self-confidence and activation between genders ( $>>0.05$ ); goal setting, commitment, stress reactions, fear control, relaxation, focusing, refocusing, imagery, mental practice and competition planning significantly differed between genders $(\mathrm{p}<0.05$ and $p<0.001)$. Students studying physical education were not significantly different from those studying fine arts in terms of goal setting, self-confidence, commitment, stress reactions, fear control, relaxation, activation, focusing, refocusing, imagery and mental practice $(\mathrm{p}>0.05)$. The students with five-year or longer history of doing sports got significantly higher scores for goal setting, self-confidence, commitment, activation, focusing, refocusing, imagery, mental practice and planning competition than those with one-four-year history of doing sports $(p<0.05$ and $\mathrm{p}<0.001)$. In conclusion, physical education and fine arts education had similar effects on mental skills. However, gender and history of doing sports had different effects on mental skills. Physical education and fine arts education had positive effects on mental skills, especially self-confidence. It can be recommended that students studying physical education should be offered information about arts and that students studying fine arts should be given information about sports. In addition, people receiving informal education about sports should be supported in terms of stress and relaxation.

Keywords: Sports, Art, Mental skill, Student, Imagination, Self-reliance, Target.

Citation | Meliha Uzun Dönmez; Osman İmamoğlu (2020). Examining Effects of Physical Education and Fine Arts Education on Mental Skills. Journal of Education and e-Learning Research, $7(2): 110-115$.

History:

Received: 20 January 2020

Revised: 28 February 2020

Accepted: 1 April 2020

Published: 23 April 2020

Licensed: This work is licensed under a Creative Commons

Attribution 3.0 License (cc) By

Publisher: Asian Online Journal Publishing Group
Acknowledgement: Both authors contributed to the conception and design of the study.

Funding: This study received no specific financial support.

Competing Interests: The authors declare that they have no conflict of interests.

Transparency: The author confirms that the manuscript is an honest, accurate, and transparent account of the study was reported; that no vital features of the study have been omitted; and that any discrepancies from the study as planned have been explained.

Ethical: This study follows all ethical practices during writing.

\section{Contents}

1. Introduction

2. Method 


\section{Contribution of this paper to the literature}

The aim of this study was to investigate effects of physical education and fine arts education on mental skills for University students. Determining the effect of sports education and fine arts education on mental skills in university students is an important issue.

\section{Introduction}

Many researchers have associated success with motoric features. However, not only motoric features but also mental factors play an important role in success. In addition, heredity, abilities and skills and social problems have an important role in success in sports. The forgoing factors alone may not account for achievements in sports (Erhan, Güler, Ağduman, \& Gerek, 2015). Planned and regular physical activity and sports are vitally important concepts to protect human health. The mental-physical and social positive effects of participation in sports activities on individuals have a significant dimension (Köse \& Kirişci, 2020). To have high performance in sports activities, it is necessary to learn about and improve several psychological skills such as motivation, concentration, focusing attention on one point, goal setting, self-confidence, positive thinking and mood and control (Neff, 2006). Mental training is one of the important tools used in psychology in general and applied sports psychology in particular and in solutions of related problems. It is a psychological skill and is a powerful tool for enhancement of athletic performance. Mental training not only has a positive influence on performance during competitions but also is a concept athletes must keep in their mind when they have disabilities and get prepared for competitions. It must be implemented both to improve psychological status of athletes and shorten the duration of recovery especially in disabilities. Furthermore, using mental training shortens duration of learning needed for physical training, facilitates performing activities properly, reduces the risk of disabilities and helps athletes keep their feelings under control (Altıntaş \& Akalan, 2008).

Goal setting is determining goals and objectives which provide motivation and guidance (Burton, 1993). Selfconfidence is the beliefs of individuals in their skills and goals (Vealey, 1986). Commitment means that individuals focus on and are devoted to their goals (Orlick, 1992). Stress reactions involve responses to demands (Selye, 1993). Fear control is an ability to cope with things and situations causing anxiety and fear (Rotella \& Lerner, 1993). Relaxation makes reduction of worries and restlessness possible (Williams \& Harris, 1998). Activation is a process which boosts physiological and mental status of individuals when they need to increase their energy, motivation and concentration (Zaichkowsky \& Takenaka, 1993). Focusing is an ability to direct and sustain attention in accordance with a goal (Nideffer \& Sagal, 1998). Refocusing is an ability to regain concentration in cases of distracted attention (Orlick, 1992). Imagery involves making use of feelings and opinions to imagine different situations (Murphy \& Jowdy, 1992). It is a process when athletes practice physical skills and rehearse a game in their mind without moving their body overtly (Murphy \& Jowdy, 1992). Competition planning involves making a plan to guide opinions, feelings and actions before, during and after a competition (Ceylan \& Imamoğlu, 2019), (Orlick. \& Partington, 1988). Persons differ in how they think about emotions and it is becoming increasingly clear that these varying beliefs are many consequential (Goodman, Kashdan, \& Imamoğlu, 2020).

The aim of this study was to reveal effects of physical education and fine arts education on mental skills of university students and effects of gender and history of doing sports on mental skills in students studying physical education.

\section{Method \\ 2.1. Participants}

The study included university students studying physical education and fine arts, volunteering to participate in the study and aged 17-28 years. A descriptive characteristics form and the Ottawa Mental Skills Assessment Tool3 (OMSAT-3) were administered to students in departments of physical education and fine arts in their free time before and after classes in the academic year of 2018-2019. Data from 344 students completely filling in the data collection tools were analyzed.

\subsection{Data Collection Tools}

Descriptive Characteristics Form: The descriptive characteristics form is composed of questions about gender, age and type of education in all the participants and experiences of doing sports in the participants studying physical education.

The Ottawa Mental Skills Assessment Tool -3: The OMSAT-3, developed by Durand-Bush, Salmela, and Green-Demers (2001) and tested for its validity and reliability in the Turkish population by Erhan et al. (2015) was used to collect data about mental skills of the athletes. The tool is a seven-point-Likert scale; one corresponding to completely disagree, two disagree, three partly disagree, four can't decide, five partly agree, six agree and seven totally agree. It is composed of 48 items, and 12 subscales; i.e. goal setting related to motivation for goals and scheduled goals, self-confidence related to beliefs in goals and skills, commitment related to focusing on goals, stress reactions related to responses to demands, fear control related to opinions, anxiety and ability to cope, relaxation related to reduction of restlessness and anxiety levels, activation related to a process increasing energy and physiological and mental status, focusing related to carefully directing and sustaining attention in line with goals, refocusing related to concentrating again when attention is distracted, imagery related to benefiting from feelings and opinions to imagine things, mental practice related to rehearsing physical skills and activities in mind without physical movements and competition planning related to reaching a goal by guiding feelings and movements during a competition. The items loaded on the subscales were as follows: questions 1, 10, 23 and 41 on goal setting, questions 2,12, 28 and 48 on self-confidence, questions 39, 17, 30 and 7 on commitment, questions 36, 14,32 and 6 on stress reactions, questions 3,19, 29 and 42 on relaxation, questions 24, 43, 4 and 16 on fear control, questions $37,5,20$ and 46 on activation, questions $31,38,15$ and 8 on focusing, questions 34, 27, 22 and 44 on refocusing, questions 26, 9, 18 and 33 on imagery, questions 45, 13, 21 and 35 on mental practice and questions 47, 40, 11 and 25 on competition planning (Erhan et al., 2015; Marius, Dobosi, Ioan, \& Prodea, 2011). 


\subsection{Statistical Analysis}

Obtained data were analyzed with the Statistical Package Program for Social Sciences 23.00. Comparisons were made with $t$ test. Statistical significance was set at $\mathrm{p}<0.05$. The validity coefficient for OMSAT-3 was found to be 0.87 in the present study.

\section{Results}

\begin{tabular}{l|c|c|c|c|c}
\multicolumn{1}{c}{ Table-1. The Comparison of the students according to their age, height, weight and body mass index } \\
\hline Variable & Sex & N & Mean & SD & t test \\
\hline \multirow{2}{*}{ Age (Year) } & Male & 188 & 21.42 & 3.61 & \multirow{2}{*}{0.70} \\
\cline { 2 - 5 } & Female & 156 & 21.36 & 3.52 & \\
\hline \multirow{2}{*}{ Height $(\mathrm{cm})$} & Male & 188 & 172.35 & 4.32 & \multirow{2}{*}{$-5.16^{* *}$} \\
\cline { 2 - 5 } & Female & 156 & 168.90 & 4.76 & \\
\hline \multirow{2}{*}{ Weight $(\mathrm{kg})$} & Male & 188 & 71.54 & 8.32 & \multirow{2}{*}{$-5.13^{* *}$} \\
\cline { 2 - 5 } & Female & 156 & 67.07 & 8.04 & \\
\hline Body Mass Index $\left(\mathrm{kg} / \mathrm{m}^{2}\right)$ & Male & 188 & 24.18 & 4.01 & \multirow{2}{*}{$-3.16^{*}$} \\
\cline { 2 - 5 } & Female & 156 & 23.76 & 4,05 & \\
\hline Note: *p<0.05 and ** $<0.001$ & & & & &
\end{tabular}

The age of university students according to gender is similar $(\mathrm{p}>0.05)$. Body weights, height, and body mass indexes of students are significantly different according to gender $(\mathrm{p}<0.05$ and $\mathrm{p}<0.001)$, Table 1 .

\begin{tabular}{|c|c|c|c|c|c|}
\hline Subscales & Gender & $\mathbf{N}$ & $\mathbf{X}$ & SD & $t$ test \\
\hline \multirow[t]{3}{*}{ Goal Setting } & Female & 188 & 22.16 & 3.96 & \multirow[t]{3}{*}{$5.14^{* *}$} \\
\hline & Male & 156 & 27.34 & 3.46 & \\
\hline & Total & 344 & 26.61 & 3.72 & \\
\hline \multirow{3}{*}{ Self-Confidence } & Female & 188 & 27.13 & 3.29 & \multirow[t]{3}{*}{1.12} \\
\hline & Male & 156 & 27.78 & 3.17 & \\
\hline & Total & 344 & 27.46 & 3.23 & \\
\hline \multirow{3}{*}{ Commitment } & Female & 188 & 24.94 & 3.93 & \multirow[t]{3}{*}{$2.83^{*}$} \\
\hline & Male & 156 & 25.95 & 3.68 & \\
\hline & Total & 344 & 25.44 & 3.81 & \\
\hline \multirow[t]{3}{*}{ Stress Reactions } & Female & 188 & 21.31 & 5.29 & \multirow[t]{3}{*}{$5.16^{* *}$} \\
\hline & Male & 156 & 23.09 & 4.28 & \\
\hline & Total & 344 & 22.21 & 4.78 & \\
\hline \multirow{3}{*}{ Fear Control } & Female & 188 & 20.37 & 5.38 & \multirow[t]{3}{*}{$5.31 * *$} \\
\hline & Male & 156 & 22.81 & 4.30 & \\
\hline & Total & 344 & 21.59 & 4.84 & \\
\hline \multirow{3}{*}{ Relaxation } & Female & 188 & 25.03 & 3.53 & \multirow[t]{3}{*}{$2.98^{*}$} \\
\hline & Male & 156 & 25.83 & 3.62 & \\
\hline & Total & 344 & 25.43 & 3.58 & \\
\hline \multirow[t]{3}{*}{ Activation } & Female & 188 & 25.32 & 3.56 & \multirow[t]{3}{*}{1.16} \\
\hline & Male & 156 & 25.98 & 2.81 & \\
\hline & Total & 344 & 25.65 & 3.19 & \\
\hline \multirow{3}{*}{ Focusing } & Female & 188 & 20.45 & 5.14 & \multirow[t]{3}{*}{$6.09 * *$} \\
\hline & Male & 156 & 22.31 & 4.82 & \\
\hline & Total & 344 & 21.39 & 4.98 & \\
\hline \multirow{3}{*}{ Refocusing } & Female & 188 & 23.56 & 4.47 & \multirow[t]{3}{*}{$3.15^{*}$} \\
\hline & Male & 156 & 24.76 & 3.82 & \\
\hline & Total & 344 & 24.16 & 4.15 & \\
\hline \multirow[t]{3}{*}{ Imagery } & Female & 188 & 24.94 & 3.72 & \multirow[t]{3}{*}{$2.83^{*}$} \\
\hline & Male & 156 & 26.14 & 3.90 & \\
\hline & Total & 344 & 25.54 & 3.81 & \\
\hline \multirow[t]{3}{*}{ Mental Practice } & Female & 188 & 25.09 & 3.59 & \multirow[t]{3}{*}{$3.10^{*}$} \\
\hline & Male & 156 & 25.86 & 3.18 & \\
\hline & Total & 344 & 25.48 & 3.39 & \\
\hline \multirow[t]{3}{*}{ Competition Planning } & Female & 188 & 24.71 & 4.23 & \multirow[t]{3}{*}{$3.07 *$} \\
\hline & Male & 156 & 25.85 & 3.68 & \\
\hline & Total & 344 & 25.28 & 3.96 & \\
\hline
\end{tabular}

There were differences between students' mental skills (Goal Setting, Commitment, Stress Reactions, Fear Control, Relaxation, Focusing, Imagery, Mental Practice, and Competition Planning) according to gender ( $p<0.05$ and $\mathrm{p}<0.001$ ), Table 2 .

There were differences comparison of Mental Skills between the Physical Education Students and the Fine Arts Students only at Competition Planning. $(\mathrm{p}<0.05)$, Table 3. 
Table-3. The comparison of mental skills between the physical education students and the fine arts students.

\begin{tabular}{|c|c|c|c|c|c|}
\hline Subscales & Type of Education & $\bar{n}$ & $\bar{X}$ & SD & t test \\
\hline \multirow[t]{2}{*}{ Goal Setting } & Physical Education & 184 & 26.64 & 3.31 & \multirow[t]{2}{*}{1.82} \\
\hline & Fine Arts Education & 160 & 26.66 & 4.14 & \\
\hline \multirow[t]{2}{*}{ Self-Confidence } & Physical Education & 184 & 27.54 & 3.05 & \multirow[t]{2}{*}{1.13} \\
\hline & Fine Arts Education & 160 & 27.38 & 3.27 & \\
\hline \multirow[t]{2}{*}{ Commitment } & Physical Education & 184 & 25.80 & 3.33 & \multirow[t]{2}{*}{0.89} \\
\hline & Fine Arts Education & 160 & 25.08 & 4.04 & \\
\hline \multirow[t]{2}{*}{ Stress Reactions } & Physical Education & 184 & 22.23 & 5.05 & \multirow[t]{2}{*}{1.77} \\
\hline & Fine Arts Education & 160 & 22.19 & 4.35 & \\
\hline \multirow{2}{*}{ Fear Control } & Physical Education & 184 & 21.64 & 5.32 & \multirow[t]{2}{*}{1.13} \\
\hline & Fine Arts Education & 160 & 21.57 & 4.35 & \\
\hline \multirow[t]{2}{*}{ Relaxation } & Physical Education & 184 & 25.59 & 3.53 & \multirow[t]{2}{*}{1.79} \\
\hline & Fine Arts Education & 160 & 25.27 & 3.69 & \\
\hline \multirow[t]{2}{*}{ Activation } & Physical Education & 184 & 25.72 & 2.70 & \multirow[t]{2}{*}{1.89} \\
\hline & Fine Arts Education & 160 & 25.58 & 3.51 & \\
\hline \multirow[t]{2}{*}{ Focusing } & Physical Education & 184 & 21.49 & 5.10 & \multirow[t]{2}{*}{1,16} \\
\hline & Fine Arts Education & 160 & 21.27 & 4.58 & \\
\hline \multirow[t]{2}{*}{ Refocusing } & Physical Education & 184 & 24.19 & 4.38 & \multirow[t]{2}{*}{1.12} \\
\hline & Fine Arts Education & 160 & 24.13 & 3.88 & \\
\hline \multirow[t]{2}{*}{ Imagery } & Physical Education & 184 & 25.56 & 3.39 & \multirow[t]{2}{*}{ 1. 09} \\
\hline & Fine Arts Education & 160 & 25.52 & 4.23 & \\
\hline \multirow[t]{2}{*}{ Mental Practice } & Physical Education & 184 & 25.52 & 3.36 & \multirow[t]{2}{*}{1.13} \\
\hline & Fine Arts Education & 160 & 25.43 & 3.39 & \\
\hline \multirow[t]{2}{*}{ Competition Planning } & Physical Education & 184 & 26.22 & 4.17 & \multirow[t]{2}{*}{$2.51^{*}$} \\
\hline & Fine Arts Education & 160 & 24.35 & 3,67 & \\
\hline
\end{tabular}

Note: ${ }^{*} \mathrm{p}<0.05$

Table-4. The Comparison of mental skills in the physical education students according to the year of doing sports.

\begin{tabular}{|c|c|c|c|c|c|}
\hline Subscale & Year & $\mathbf{N}$ & $\mathbf{X}$ & SD & $t$ test \\
\hline \multirow[t]{2}{*}{ Goal Setting } & $1-4$ years & 78 & 23.01 & 3.92 & \multirow[t]{2}{*}{$6.19^{* *}$} \\
\hline & 5 years or more & 106 & 26.08 & 3.43 & \\
\hline \multirow[b]{2}{*}{ Self-Confidence } & $1-4$ years & 78 & 24.13 & 3.26 & \multirow[t]{2}{*}{$5.18^{* *}$} \\
\hline & 5 years or more & 106 & 27.48 & 3.14 & \\
\hline \multirow[b]{2}{*}{ Commitment } & $1-4$ years & 78 & 21.09 & 3.89 & \multirow[t]{2}{*}{$4.16^{* * *}$} \\
\hline & 5 years or more & 106 & 23.37 & 3.64 & \\
\hline \multirow[t]{2}{*}{ Stress Reactions } & $1-4$ years & 78 & 23.09 & 5.24 & \multirow[t]{2}{*}{$5.22 * *$} \\
\hline & 5 years or more & 106 & 21.31 & 4.24 & \\
\hline \multirow[b]{2}{*}{ Fear Control } & $1-4$ years & 78 & 20.27 & 5.33 & \multirow[t]{2}{*}{$5.34 * *$} \\
\hline & 5 years or more & 106 & 22.66 & 4.26 & \\
\hline \multirow[b]{2}{*}{ Relaxation } & $1-4$ years & 78 & 26.74 & 3.49 & \multirow[t]{2}{*}{$5.16^{* * *}$} \\
\hline & 5 years or more & 106 & 24.43 & 3.58 & \\
\hline \multirow[t]{2}{*}{ Activation } & 1-4 years & 78 & 24.44 & 3.52 & \multirow[t]{2}{*}{$3.25^{*}$} \\
\hline & 5 years or more & 106 & 26.99 & 2.78 & \\
\hline \multirow[b]{2}{*}{ Focusing } & $1-4$ years & 78 & 20.46 & 5.09 & \multirow[t]{2}{*}{$6.03 * *$} \\
\hline & 5 years or more & 106 & 22.51 & 4.77 & \\
\hline \multirow[b]{2}{*}{ Refocusing } & $1-4$ years & 78 & 22.56 & 4.43 & \multirow[t]{2}{*}{$6.12 * *$} \\
\hline & 5 years or more & 106 & 25.83 & 3.78 & \\
\hline \multirow[t]{2}{*}{ Imagery } & $1-4$ years & 78 & 24.24 & 3.68 & \multirow[t]{2}{*}{$2.87^{*}$} \\
\hline & 5 years or more & 106 & 26.87 & 3.86 & \\
\hline \multirow[t]{2}{*}{ Mental Practice } & $1-4$ years & 78 & 24.29 & 3.55 & \multirow[t]{2}{*}{$3.19^{*}$} \\
\hline & 5 years or more & 106 & 26.74 & 3.15 & \\
\hline \multirow[t]{2}{*}{ Competition Planning } & $1-4$ years & 78 & 25.51 & 4.19 & \multirow[t]{2}{*}{$3.09^{*}$} \\
\hline & 5 years or more & 106 & 26.94 & 3.64 & \\
\hline
\end{tabular}

There were differences the comparison of Mental Skills in the Physical Education Students according to the year of doing sports $(\mathrm{p}<0.05$ and $\mathrm{p}<0.001)$, Table 4 .

\section{Discussion and Conclusion}

In the present study, although age did not significantly differ between genders ( $p>0.05)$; height, weight and body mass index were significantly different in favor of males $(\mathrm{p}<0.05$ and $\mathrm{p}<0.001)$, Table 1 . Body mass indexes of $20-25 \mathrm{~kg} / \mathrm{m}^{2}$ are considered as a criterion for being healthy (Imamoğlu, Ağaoğlu, \& Eker, 2010). The students included in the current study can be regarded as healthy based on their body mass indexes.

In a study by Shokoufeh (2018) mental skills scores were significantly different between male and female athletes. Nicholls et al. reported that males had higher mental stability and that females got lower scores for selfconfidence and anxiety (Nicholls, Polman, Levy, \& Backhouse, 2009). Güler and Erhan (2017) found a significant difference in mental skills between age groups. Ceylan and Imamoğlu (2019) detected a significant difference in the mental skills competition planning, mental practice, imagery, focusing, refocusing, relaxation, stress reactions, goal setting and commitment between genders. In the present study, whereas no significant difference was found in selfconfidence and activation between genders ( $p>0.05$ ); competition planning, mental practice, imagery, focusing, refocusing, relaxation, stress reactions, goal setting and commitment were significantly different $(\mathrm{p}<0.05$ and $\mathrm{p}<0.001)$, Table 2 . The males were found to be better at all mental skills. 
Güler and Erhan (2017) showed a significant difference between mental skills subscales and age, types of sports, contact levels, sports experience and age of starting sports in athletes doing different types of sports. Ceylan and Imamoğlu (2019) reported similar mental skills scores between physical education students and fine arts students. In the present study, the physical education students and fine arts students did not differ significantly in terms of goal setting, self-confidence, commitment, stress reactions, fear control, relaxation, activation, focusing, refocusing, imagery and mental practice $(\mathrm{p}>0.05)$. Only competition planning significantly differed in terms of types of education $(\mathrm{p}<0.05)$, Table 3 . The physical education students and fine arts students were similar in goals and objectives providing motivation and guidance, beliefs in their skills and goals, commitment and stress reactions. In addition, they were similar to each other in factors causing anxiety and fear and skills to cope with them, reduction of anxiety and restlessness, motivation and focusing, focusing on a certain point, regaining effective concentration when their attention is distracted, mental practice and imagery. It is not surprising that the physical education students got higher scores for competition planning since it involves making plans guiding opinions, feelings and actions before, during and after a competition. It can also be attributed to the fact that physical education students join competitions.

Exercise and physical activity improve physical and mental health and the quality of life (Aksoy \& Arslan, 2019). The purposes of doing sports in societies can vary with their histories such as ensuring the unity of the society, helping individuals become mature or getting rid of stress (Atan et al., 2014). Education can create positive changes in transient personality characteristics (Koca, Imamoğlu, \& İmamoğlu, 2018). Many educators have agreed that doing sports plays a role in personality development (Atan, Tural, Imamoğlu, Ciçek, \& Tural, 2012). Doing sports can help develop leadership skills (Cetinkaya \& Imamoğlu, 2018). Ceylan and Imamoğlu (2019) revealed in their study that university students got high scores for the OMSAT-3. Each subscale of the OMSAT-3 has four questions. When the fact that it is a seven-point Likert scale, the lowest and highest scores for each subscale can be 4 and 28 respectively. In the present study, the subscale scores showed that the male students had better mental skills. Both physical education and fine arts students were similar in their mental skills and had good mental skills. Both physical education and fine arts students got the highest scores for self-confidence.

Acting sports has positive effects on human health and personality (Imamoğlu. \& Demirtaş O., 2017). In the current study, the students with history of doing sports lasting five years or more got higher scores for goal setting, self-confidence, commitment, fear control, activation, focusing, refocusing, imagery, mental practice and competition planning compared to those with history of doing sports lasting one-four years $(\mathrm{p}<0.05$ and $\mathrm{p}<0.001)$. However, the latter group had higher scores for stress reactions and relaxation $(p<0.05)$, Table 4 . This can be explained by the fact that the participants with longer history of doing sports might have more frequently joined competitions. Higher scores of the participants with longer history of sports for all subscales except stress reactions and relaxation can be ascribed with their education about sports, effects of their training and their experiences.

To conclude, physical education and fine arts education are generally similar in their effects on mental skills. However, mental skills can vary with history of doing sports in the physical education students and gender. Fine arts education and physical education can be the most effective in self-confidence. It can be suggested that physical education students should be offered information about arts and that fine arts education students should be given information about sports. In addition, students having informal education for sports should be provided support in terms of stress and relaxation.

\section{References}

Aksoy, Y., \& Arslan, O. (2019). Effects of recreational activity on leisure barriers between students. Asian Journal of Education and Training, 5(4), 569-574.Available at: https://doi.org/10.20448/journal.522.2019.54.569.574

Altıntaş, A., \& Akalan, C. (2008). Mental training and high performance. Spormetre Journal of Physical Education and Sports Sciences, 6(1), 3943.

Atan, T., Güllü, E., Çiçek, G., İmamoğlu, O., Yamaner, F., \& Ünlü, C. (2014). Effects of two different exercise on life satisfaction and beck depression level. Journal of Education and Sociology, 5(1), 18-23.

Atan, T., Tural, E., Imamoğlu, O., Ciçek, G., \& Tural, S. (2012). Physical activity levels of teachers and health professionals in Turkey. Health MED, 6(6), 1935-1942.

Burton, D. (1993). Goal setting in sport. In R.N. Singer, M. Murphey, \& L. K. Tennant (Eds), Handbook of research on sport (pp. 467-491). New York: Macmillan.

Cetinkaya, G., \& Imamoğlu, G. (2018). Research on leadership tendency of students taking sports education according difference variations. The Journal of International Social Research, $11(59), 719-725$.

Ceylan, L., \& Imamoğlu, G. (2019). The effect of fine arts education and sports education on mental ability. Paper presented at the 5th International Eurasian Congress on Natural Nutrition, Healthy Life \& Sport, Proceedings Book, 1880-1885.

Durand-Bush, N., Salmela, J. H., \& Green-Demers, I. (2001). The Ottawa mental skills assessment tool (OMSAT-3*). The Sport Psychologist, 15(1), 1-19.Available at: https://doi.org/10.1123/tsp.15.1.1.

Erhan, E., Güler, M. Ş., Ağduman, F., \& Gerek, Z. (2015). Ottawa mental ability assessment scale-3 Turkish validity and reliability Study, Kafkas Universty. E - Kafkas Journal of Educational Research, 2(2), 33-39.

Goodman, F. R., Kashdan, T. B., \& Imamoğlu, A. (2020). Valuing emotional control in social anxiety disorder: A multimethod study of emotion beliefs and emotion regulation. Emotion (Washington, DC). USA,APA PsycArticles. Retrieved from: https://www.ncbi.nlm.nih.gov/pubmed/32191093.

Güler, M. Ş., \& Erhan, E. S. (2017). The evaluation of mental abilities of athletes in different branches. European Journal of Physical Education and Sport Science, $17(10), 311-328$.

Imamoğlu, O., Ağaoğlu, S., \& Eker, H. (2010). The investigation of nutritional habits of department of physical education and sports students in different cities. Journal of Physical Education and Sport Science, 12(4), 1-12.

Imamoğlu., G., \& Demirtaş O. (2017). Investigation of students' views who receive art and religious training about body image. International Journal of Cultural and Social Studies, 3(Special Issue 2), 476-483.

Koca, F., Imamoğlu, G., \& İmamoğlu, O. (2018). Sports status of high school students and investigation of personality characteristics by gender. The Journal of Academic Social Science, 6(80), 31-42.

Köse, B., \& Kirişci, İ. (2020). Comparison of causes and treatment methods of injuries in football, basketball, handball, volleyball branches. Spormetre Journal of Physical Education and Sports Sciences, 18(1), 235-241.

Marius, C., Dobosi, S., Ioan, N., \& Prodea, C. (2011). A confirmatory factor analysis of the Ottawa Mental Skill Assessment Tool (OMSAT3*)-Romanian version. Human Movement, 12(2), 159-164.Available at: https://doi.org/10.2478/v 10038-01 1-0014-x. 
Murphy, S. M., \& Jowdy, D. P. (1992). Imagery and mental practice. In T.S. Horn (Ed), Advance in sport psychology (pp. 221-250). Champaign, IL: Human Kinetics.

Neff, R. (2006). Mental training for athletes and other performers; Retrieved from: www.mentaltraininginc.com 2010.

Nicholls, A. R., Polman, R. C., Levy, A. R., \& Backhouse, S. H. (2009). Mental toughness in sport: Achievement level, gender, age, experience, and sport type differences. Personality and individual differences, 47(1), 73-75.Available at: https://doi.org/10.1016/j.paid.2009.02.006.

Nideffer, R. M., \& Sagal, M. (1998). Concentration and attention control. . In J.M. Williams (Ed), Applied sport psychology: Personal growth to peak performance (3rd ed., pp. 296-315). Mountain view, CA: Mayfield.

Orlick, T. (1992). The psychology of personal excellence. Contemporary Thought on Performance Enhancement, 1(1), $109-122$.

Orlick., T., \& Partington, J. (1988). Mental links to excellence. The Sport Psychologist, 2(2), 105-130.Available at: https://doi.org/10.1123/tsp.2.2.105.

Rotella, R. J., \& Lerner, J. D. (1993). Responding to competitive pressure. Handbook of research on sport psychology (pp. 528-541). New York: Macmillan.

Shokoufeh, S. (2018). Turkey elite men and women wrestlers sedentary individuals with mental ability, Leadership and Investigation of Aggression Levels. Ondokuz Mayss University, Institute of Health Sciences, Ph.D. Thesis, Samsun, 8-70.

Vealey, R. S. (1986). Conceptualization of sport-confidence and competitive orientation: Preliminary investigation and instrument development. Journal of Sport and Exercise Psychology, 8(3), 22 1-246.Available at: https://doi.org/10.1 123/jsp.8.3.221.

Williams, J. M., \& Harris, D. V. (1998). Relaxation and energizing techniques for regulation of arousal. In J.M., Williams (Ed), Applied sport psychology: Personal growth to peak performance (3rd ed., pp. 219-236). Mountain View,CA: Mayfield.

Zaichkowsky, L., \& Takenaka, K. (1993). Optimizing arousal level. In. Singer RN, Murphey M, Tennant LK eds. Handbook of Research on Sport Psichology. 